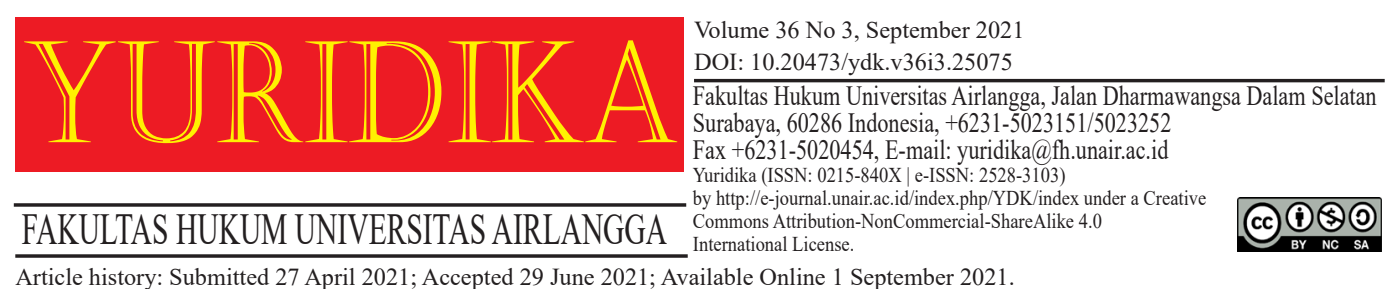

\title{
Analysis of Renewable Energy Directive II on Trading of Indonesian Palm Oil Associated with the GATT
}

\author{
Amanda Fadhilla Chairunisa and Imam Haryanto \\ Amandafdhilla@gmail.com \\ Universitas Pembangunan Nasional Veteran Jakarta
}

\begin{abstract}
International economic relations and the policies that regulate them are important for countries. In this study, the authors analyse how the Renewable Energy Directive (RED) II policy, a derivative of the European Union's (EU) RED policy, will affect the Indonesian palm oil trade. It also examines the violations of previous policies, including the General Agreement on Tariffs and Trades (GATT). The authors show that the GATT regulates how international trade relations should be carried out, and any violations of this international agreement could affect economic relations between the two countries on micro and macro scales. The authors adopt normative juridical methods for the study, basing their legal research on library and secondary materials. This study reflects on how RED II can affect trade in Indonesian palm oil products. When RED II went into effect in 2021, the EU violated the nondiscrimination principle in GATT 1947.
\end{abstract}

Keywords: International Trades Law; CPO; RED II; GATT 1947.

\section{Introduction}

For some states, economic growth is a top priority. Several approaches can help achieve economic growth, including establishing bilateral and multilateral international trade relations. International trade relations include micro and macro aspects. The micro aspect relates to how a market relationship will affect employment opportunities; the macro aspect relates to international trade issues (export-import). ${ }^{1}$ One form of economic globalisation is export-import activity, and one of the most-traded products is palm oil.

Southeast Asian countries produce about $89 \%$ of the world's total palm oil production. Indonesia is the largest exporter and producer of palm oil. In 2016,

\footnotetext{
${ }^{1}$ Emmy Lilimantik, Kebijakan Ekonomi Internasional (FPK UNLAM 2015).[2].
} 
Indonesia produced $36,000,000$ metric tons of palm oil. ${ }^{2}$ As much as $70 \%$ of the product is exported to various countries, including European Union (EU) Member States. Based on EU data, over the past five years, Indonesia has exported 3.6 tonnes of palm oil to the EU, generating an annual income of EUR 2.3 billion. ${ }^{3}$

Countries and international organisations promote free trade through free trade agreements. More formal international cooperation was introduced after World War II, specifically with the General Agreement on Tariffs and Trade (GATT) in 1947. ${ }^{4}$ The GATT is an international trade agreement that binds countries to create a free and fair trade ecosystem that helps shape economic growth and development in the global community. As Law No 7 of 1994 About Ratification of the Agreement Establishing the World Trade Organization noted, more than 125 countries follow the GATT. GATT 1947 is one of the multilateral agreements attached to the World Trade Organization (WTO) agreement. ${ }^{5}$

The WTO Agreement binds all members. Indonesia joined the WTO in 1995 as an original member. ${ }^{6}$ The EU also joined the WTO in 1995, representing European countries. As a multilateral international agreement containing international trade regulations, the GATT had stipulated that trade relations between member countries must be carried out without discrimination (non-discrimination principle). Countries bound to the GATT were not allowed to treat a country less favourably than other countries, as stated in Law No 7 of 1994.

Renewable Energy Directive II, which took effect in January 2021, is an

\footnotetext{
${ }^{2}$ Indonesia Investments, 'Minyak Kelapa Sawit' (Indonesia Investments, 2017) <www. indonesia-investments.com/id/bisnis/komoditas/minyaksawit/item166\#: :text=Indonesia adalah produsen dan eksportir terbesar minyak sawit di dunia.\&text=Produksi minyak sawit dunia didominasi,eksportir minyak sawit yang terbesar> accessed 16 October 2020.

3 Sfr Antara, 'Dubes Uni Eropa Bantah Larangan Impor Sawit Dari Indonesia' (CNN Indonesia, 2019) <www.cnnindonesia.com/ekonomi/20191212135827-92-456346/dubes-unieropa-bantah-larangan-impor-sawit-dari-indonesia> accessed 16 October 2020.

${ }^{4}$ Tim Bank Indonesia, Kerja Sama Perdagangan Internasional: Pejuang Dan Tantangan Bagi Indonesia (PT Elex Media Komputindo 2007).[2].

${ }^{5}$ UU no 7 Tahun 1994 tentang Pengesahan Agreement Establishing the World Trade Organization (Persetujuan Pembentukan Organisasi Perdagangan Dunia).

${ }^{6}$ E Retno Kadarukmi, 'Dampak Implementasi GATT/WTO Terhadap Ekspor Impor Indonesia’ (2013) 9 Jurnal Administrasi Bisnis.
} 
EU policy ${ }^{7}$ regulating energy to reduce emissions and pollutants. RED II refines the RED policy. ${ }^{8}$ The EU plans to reduce the number of palm oil imports to EU countries. ${ }^{9}$ This plan is suspected of discriminating against the Indonesian palm oil industry, which exports palm oil products to several EU member countries.

For these reasons, the authors analyse and discuss how the EU's RED II affects the GATT as an international agreement and as a form of discrimination against the Indonesian palm oil trade. This research uses descriptive research, a fact-finding method that describes in detail what event or situation is taking place. The authors also use the normative juridical approach to explore theories, concepts, legal principles, and laws and regulations related to this research.

The sources for normative juridical legal research include secondary data. Secondary data sources include primary, secondary and tertiary legal materials such as Law No 37 of 1999 concerning Foreign Relations, Law No 7 of 2014 concerning Trade, Law Number 7 of 1994 concerning Ratification of the Agreement Establishing the World Trade Organization (Approval for the Establishment of the World Trade Organization), Minister of Agriculture Regulation No 19/Permentan/ OT/140/3/2011 concerning Guidelines for Indonesian Sustainable Palm Oil (ISPO), RED II and GATT, which is part of the WTO (World Trade Organization) Agreement. The legal materials for this research came from primary and secondary materials with literature studies. The authors searched and inventoried rules or concepts, theories, opinions, or findings closely related directly or indirectly to the subject matter of this study

\footnotetext{
${ }^{7}$ International Council on Clean Transportation, 'The European Commission's Renewable Energy Proposal for 2030' (ICCT, 2017) < https://theicct.org/sites/default/files/publications/RED II_ICCT_PolicyUpdate_vF_jan2017.pdf $>$ accessed 16 October 2020.

${ }^{8}$ Andre Ahmad Stiadi, 'Potensi Dampak Penerapan RED II Terhadap Perekenomian Indonesia' (Psdr.lipi, 2020)<http://psdr.lipi.go.id/news-and-events/opinions/potensi-dampak penerapan-red-iiterhadap-perekenomian-indonesia.html> accessed 21 October 2020.

${ }^{9}$ European Union, 'Directive (Eu) 2018/2001 of the European Parliament and of the Council of 11 December 2018 on the Promotion of the Use of Energy from Renewable Sources (Recast)' (Official Journal of the European Union, 2018) <https://eur-lex.europa.eu/legalcontent/EN/TXT/?uri=uriserv:OJ.L_.2018.328.01.0082.01.ENG\&toc=OJ:L:2018:328:TOC 9> accessed 26 October 2020 .
} 


\section{The Problem with RED II}

Enacted in 2018 and effective in 2021, RED II is a policy that has led to controversy in several countries, especially within the palm oil industry. Indonesia is one of the countries affected. The authors analyse how RED II has violated the non-discriminatory principles contained in GATT 1947, wherein all countries must feel they have benefited from a trade policy determined by the state. ${ }^{10}$

\section{What Is the Renewable Energy Directive?}

RED II was preceded by RED, which was promulgated in 2009. The 2009 RED had been an effective legal tool regulating how palm oil products are ordered as product sequence. of other Indonesian export products that enter the EU member countries.

RED came out of the EU's dependency on fossil fuel energy sources and is the first EU Sustainable Development Strategy produced in negotiations held by the European Council in Göteborg in 2013. RED is part of the EU development policy that depends more on renewable energy sources. Because it is still in a strategic form, this framework does not have the legal force to bind EU Member States. There were several changes and amendments between 2005 and 2009. In 2009, the European Parliament and European Council finally approved RED.

RED aims to increase energy security, reduce greenhouse gas (GHG) emission levels and make changes related to the use of fossil fuels in the form of renewable energy. The RED policy was made to implement the Kyoto protocol, ${ }^{11}$ reduce GHG emissions by $20 \%$ and reduce dependence on imported fuels.

Furthermore, RED aims to increase the use of domestically produced energy, specifically renewable energy, in the EU. RED regulates that EU members should

\footnotetext{
${ }^{10}$ Revy S M Korah, 'Prinsip-Prinsip Eksistensi General Agreement on Tariffs and Trade (GAAT) Dan World Trade Organization (WTO) Dalam Era Pasar Bebas' (2016) 22 Jurnal Hukum Unsrat $<$ https://ejournal.unsrat.ac.id/index.php/jurnalhukumunsrat/article/view/13198>.

${ }^{11}$ Rosita Dewi, 'Implementasi Renewable Energy Directive Uni Eropa Sebagai Hambatan Non Tarif Perdagangan’ (2013) 1 Jurnal Interdependence < https://core.ac.uk/download/pdf/268076071. pdf $>$.
} 
use renewable energy in transportation at least $10 \%$ and other aspects (industry, households and electricity needs) at least $20 \%$ by 2020 . This initial figure is based on the achievements of Malta breaking through the lowest rate at 10\% and Sweden breaking through the highest rate at 49\%. RED also regulates the minimum amount of NRE use and the criteria for the proper use of biofuel-based energy in the EU. These criteria include low emission of GHG, sustainability, paying attention to environmental sustainability, and not destroying forestry lands or local state plantations, especially in producing energy. ${ }^{12}$

Besides renewable energy, the EU is also directing its members to use this directive policy to preserve the environment. Member States must comply with the EU's environmental safety standards. Therefore, several standard criteria have been mentioned above and must be adjusted to the imported products that enter EU member countries, especially in their biofuels. In this case, there is still debate about whether Indonesian Crude Palm Oil (CPO) products are acceptable under EU laws and regulations.

A 2017 EU study noted more than 10 million hectares of palm oil plantation in Indonesia, with approximately $40 \%$ planted by smallholder farms. The global trade in palm oils is likely causing the conversion of more than half of the forest area into palm oil plantations. The EU is estimated to be responsible for 0.9 million hectares of deforestation of forest area through imports activity of palm oil between 1980 and 2000. ${ }^{13}$ This deforestation has caused Europeans to worry about the emergence of GHG emissions.

Furthermore, the planting of palm oil affects not only nature but also the socioeconomy. Data from the abovementioned 2017 study found that palm oil increases income for many rural people (including smallholder farmers), supports rural

\footnotetext{
${ }^{12}$ Andreas Lendle and Malorie Schaus, Sustainability Criteria in the EU Renewable Energy Directive: ICTSD Information Note No 2, September 2010 (International Centre for Trade and Sustainable Development 2010).[1-3].

${ }^{13} 3$ Keel LLP and LMC International Ltd, Study on the Environmental Impact of Palm Oil Consumption and on Existing Sustainability Standards (Publications Office of the European Union 2018).[17].
} 
economic development and helps the economy of the producing country. However, it is also often associated with social concerns, including land use rights, forced labour, underage workers, and problems related to labour terms and conditions such as low wages and discrimination.

Furthermore, a 'Report on the status of production expansion of relevant food and fees for crops worldwide' found that CPO does not fit the EU's standardisation. Specifically, the report states that palm oil produced in Indonesia had a high risk of unsustainability, the main issue from a conservation perspective. The EU claimed that palm oil production in Indonesia uses the ILUC procedure. Furthermore, the report states that palm oil production causes deforestation and high carbon areas.

The EU believes the RED policy is important. The EU is committed to the Kyoto protocol, which states that the world must reduce GHG emissions as much as possible, based on how its member countries produce energy. Therefore, on 11 December 2018, RED II was promulgated as an amendment to the RED policy.

A provision of the RED II policy states that the EU member countries will determine how to implement their reduced use of palm oil. It is possible to reduce directly to $0 \%$. Some Eastern European countries are not permanent users of renewable energy, but concern the EU Member States as they have a high percentage of use rate or a $7 \%$ share in the use of renewable energy for transportation. Immediately reducing the use of palm oils to $0 \%$ will affect the daily lives of the people of that country and fuel trading made from palm oil. Uncertainty will arise in determining quotas and using palm oil because it is unclear how the Member States will execute the policy. ${ }^{14}$

The policy can be found in article 26 point 2 of the draft RED II policy, which has been issued and will take effect in 2021.

For the calculation of a Member State's gross final consumption of energy from renewable sources referred to in Article 7 and the minimum share referred to in the first subparagraph of Article 25 (1), the share of high indirect land use

\footnotetext{
${ }^{14}$ Rosediana Suharto, 'EU Renewable Energy Directive II Dan Hambatan Perdagangan' (Sawit Indonesia, 2019) < https://sawitindonesia.com/eu-renewable-energy-directive-ii-dan-hambatan-perdagangan/> accessed 5 November 2020.
} 
change-risk biofuels, bioliquids or biomass fuels produced from food and feed crops for which a significant expansion of the production area into land with high-carbon stock is observed shall not exceed the level of consumption of such fuels in that Member State in 2019, unless they are certified to be low indirect land-use change risk biofuels, bioliquids or biomass fuels pursuant to this paragraph. From 31 December 2023 until 31 December 2030 at the latest, that limit shall gradually decrease to $0 \%$.

This article shows that only renewable energy certified as having a low risk of ILUC can enter the EU Member States. Ecofys created the ILUC company certification method but lacks standards or criteria determining the ILUC. If the standards or criteria are based on the Agreement on Technical Barriers to Trade, it is still difficult to find an appropriate standard of parameters related to the certification system. ${ }^{15}$

For the abovementioned reasons, the policies disregard the non-discrimination principles of the GATT.

\section{Non-discrimination Principle of the General Agreement on Tariffs and Trade}

The agreement officially ratified by Indonesia in 1994 is an economic agreement of the international community. Prior to 1994, the GATT was a multilateral agreement that bound more than 120 countries, including Indonesia. ${ }^{16}$ The text was harmonised through eight rounds of multilateral negotiations as follows:

1. Geneva Round (1947);

2. Annecy Round (1949);

3. Torquay Round (1950);

4. Geneva Round (1956);

5. Dillon Round (1960-61);

6. Kennedy Round (1962-67);

7. Tokyo Round (1973-79);

8. The Uruguay Round (1986-94). ${ }^{17}$

These rounds resulted in tariff reductions and an international organisation officially established in 1995 as the WTO.

\footnotetext{
${ }^{15}$ ibid.

${ }^{16}$ Huala Adolf, Pengaruh Perjanjian WTO/GATT-1994 Mengenai Penanaman Modal Asing Di Indonesia Dan Langkah Antisipasi Hukumnya (FH UNPAD 1998).

${ }^{17}$ Mitsuo Matsushita, The World Trade Organization: Law, Practice, and Policy (3rd edn, OUP 2015).[9].
} 
The WTO is an international organisation tasked with controlling trade agreements for multilateral trade. It resolves international trade disputes, forges cooperation between international institutions, controls trade policies of member countries and provides necessary technical assistance to developing member countries. Even though it was established as an official international organisation, the WTO is run based on the previous GATT agreement. In other words, the WTO cannot run without the GATT as the framework of the international economic organisation.

The GATT agreement contains several principles, one of which is the mostfavored-nation (MFN). This principle means policy between member states in the trade sector must be enforced on a non-discriminatory basis.

It is not easy to find guidelines for applying MFN because this principle can be interpreted and poured into several other forms or words. ${ }^{18}$ MFN can be interpreted as a non-discriminatory principle based on article I of the GATT, under which countries must receive equal treatment in implementing import and export policies and equal treatment in matters relating to other costs. The same treatment must be carried out immediately and unconditionally to products originating from or addressed to all GATT members. ${ }^{19}$ Article XX of the GATT also contains the principle of non-discrimination:

Subject to the requirement that such measures are not applied in a manner which would constitute a means of arbitrary or unjustifiable discrimination between countries where the same conditions prevail, or a disguised restriction on international trade, nothing in this Agreement shall be construed to prevent the adoption or enforcement by any contracting party of measures.

In international trade, hidden restrictions and discriminatory requirements from a country are not justified. All countries must be treated on an equal basis, and all countries must enjoy the benefits of a trade policy. ${ }^{20}$

In light of the GATT articles regarding non-discrimination, the RED II policy provides that only renewable energy certified as 'Low ILUC' can enter

\footnotetext{
${ }^{18}$ Lord McNair, The Law of Treaties (OUP 1961).[273].

${ }^{19}$ ibid.; Adolf (n 16).

${ }^{20}$ Adolf (n 16).
} 
the EU Member States. In Europe, palm oil products are one of the largest export commodities from Indonesia. They are included in the 'High-Risk ILUC' category according to the Delegated Act on Low and High ILUC, which is part of RED II.

This policy could affect the palm oil market in Indonesia. Moreover, RED II violates the non-discriminatory principle of the GATT in two ways. First, the EU discriminates against Indonesian palm oil products and vegetable oil products from other countries, including fuel made from soybeans. Second, the EU discriminates against Indonesian palm oil products with vegetable oil produced by EU Member States.

In other words, the EU has violated the GATT based on Lord McNair's theory that an international treaty creates an obligation for the parties to the agreement, namely countries or governments. ${ }^{21}$ International agreements, a source of international law, are binding as positive law or a principle that a country must follow based on its own will. ${ }^{22}$

\section{Palm Oil Commodities in Indonesia}

Palm oil is the top earner plantation for crop oil and gas for Indonesia, making this plant one of the favourite plants for the agricultural sector. There are bright prospects for the palm oil commodity in the global vegetable oil trade. The large amount of income generated by oil palm encourages the Indonesian government to advance the development of palm oil plantations.

The palm oil industry can be said to be bright because, in 2019, palm oil production reached 51.8 million tons or increased $9 \%$ over the previous year. The export volume in 2019 was 35.8 million tons and increased $4 \%$ over the previous year. In 2019, one of the main export destinations for palm oil from Indonesia was the EU, which reached 4.6 million tonnes. ${ }^{23}$ According to the last EU Delegation's

\footnotetext{
${ }^{21}$ ibid.; Lord McNair (n 18).

${ }^{22}$ Sefriani, Hukum Internasional: Suatu Pengantar (PT. Raja Grafindo Persada 2010).[12].

${ }^{23}$ Indonesia Association of Palm Oil Entrepreneur, 'Refleksi Industri Kelapa Sawit 2019 Dan Prospek 2020' (GAPKI, 2019) < https://gapki.id/news/16190/refleksi-industri-kelapa-sawit-2019dan-prospek-2020> accessed 7 November 2020.
} 
five-year report on import activities, around 3.5 million tonnes of palm oil entered EU member countries, producing an average of EUR 2.2 billion per year. This is a large amount for Indonesia, and the EU is one of the markets with the highest users. This means markets in the EU Member States have good market potential for export activities of palm oil commodities from Indonesia. There is increasing demand for palm oil in the EU because the Member States use sustainable energy like biodiesel to overcome environmental problems. This technology is designed to solve problems, such as lack of energy, using a sustainable or renewable resource, specifically biofuels. To be able to produce this biofuel, the EU Member States import CPO from the largest palm oil producers, including Indonesia. ${ }^{24}$

The reduction in palm oil consumption by the EU Member States is considered protection of their domestic oils, including rapeseed oil \& sunflower seed oil, based on the results of GLOBIOM research by two European companies, Ecofys and IIASA. The forest land function or the ILUC value risk of the EU's domestic oil production is far below palm oil because palm oil is the crop that produces the largest biofuel in the world market. The demand for biofuel made from palm oil is higher than other vegetable oils studied by Ecofys and IIASA, so it is likely that a wider area of land in the production process will be needed.

If the RED II policy states that this palm oil will be reduced to $0 \%$ by 2030 , the implementation of its export-import activities will impact the Indonesian palm oil industry. As a result, losses experienced by Indonesia could reach a nominal value of IDR 218.18 billion per year. This loss is due to the large export performance and the proportion of Indonesia's trade in the non-oil and gas sector, largely supported by palm oil trade relations with the EU Member States as much as $1.66 \%$ per year. $^{25}$

In addition to state income, around 3.6 million people work in the oil palm plantation sector, and 2 million oil palm farmers ${ }^{26}$ experience losses, including their

\footnotetext{
${ }^{24}$ ibid.

${ }^{25}$ Stiadi (n 8).

${ }^{26}$ News Desk, 'Millions of Indonesians to Be Affected by EU Palm Oil Policy: Japbusi' The Jakarta Post (2019) <www.thejakartapost.com/news/2019/04/24/millions-of-indonesians-to-be-affected-by-eu-palm-oil-policy-japbusi.html> accessed 8 November 2020 .
} 
jobs related to palm oil production. It is feared that the snowball effect could occur if the EU still enforces this discriminatory policy. The losses suffered by Indonesia are many, ranging from discrimination to poverty because millions of Indonesians depend on their income from the palm oil industry.

\section{Conclusion}

The export-importrelationshipbetween Indonesia and the EU benefits each other, but the enactment of the RED II policy could cause this relationship to disappear. The EU's accusation that Indonesian-produced palm oil products are not environmentally friendly has been proven wrong by research conducted by the Italian-based For Free Choice Institute. The research argues that based on the tests conducted to see which vegetable oils are the most environmentally friendly, the results prove that palm oil is the most sustainable and environmentally friendly vegetable oil compared to rapeseed and sunflower. Moreover, based on this test, palm oil is considered to have a good life cycle compared to other vegetable oils, such as canola and sunflower. ${ }^{27}$

Based on For Free Choice's study, the authors conclude that the EU's policy, which will go into effect in January 2021, is discriminatory. If the EU wants to preserve nature by using Certified Sustainable Palm Oil, they should reflect on their domestic vegetable oil - that is, rapeseed oil - which is not verified as 'sustainable' oil. Therefore, if the reason for preserving the environment is reducing the consumption of palm oil, then implementing the RED II policy in the EU Member States is not valid. Many palm oil experts from Indonesia think this policy was only made to block Indonesia's export of palm oil to the EU and increase the domestic product of their own countries. This action is wrong if we look at the GATT, which states that hidden restrictions and discriminatory requirements are not justified.

Therefore, it is most appropriate for Indonesia to bring the RED II policy to the WTO for a consultation on how the EU discriminates against the Indonesian

\footnotetext{
${ }^{27}$ Sekar Wiji Rahayu and Fajar Sugianto, 'Implikasi Kebijakan Dan Diskriminasi Pelarangan Ekspor Dan Impor Minyak Kelapa Sawit Dan Bijih Nikel Terhadap Perekonomian Indonesia’ (2020) 16 DIH: Jurnal Ilmu Hukum.[230].
} 
palm oil market. A panel has been formed to resolve this problem, consisting of the United States, Malaysia, Norway, Turkey, Singapore, Thailand, Russia, Japan, Korea, India, Honduras, Guatemala, Costa Rica, Colombia, China, Canada, Brazil and Argentina, to function as a third party to solve the EU's discriminatory actions against Indonesia.

Southeast Asian countries are the largest contributor to palm oil commodities globally. To work toward resolving this problem involving palm oil, in December 2020, the Association of Southeast Asian Nations (ASEAN) and EU foreign ministers created a Joint Working Group of Vegetable Oils that met in January 2021 to discuss a better understanding of the policy and environmental sustainability of oil palm plantations. ${ }^{28}$

The first joint working group occurred on 14 January 2021 via webinar. The Indonesian embassy in Stockholm organised this webinar to encourage discussion on sustainable vegetable oil and the background of the agreement between the EU and ASEAN Member States in enhancing the relationship from a Dialogue Partnership to a Strategic Partnership. ${ }^{29}$ The importance for the WTO in resolving the EU's discrimination is to see how many losses Indonesia will experience because millions of individuals depend on the palm oil industry and billions of Indonesian state revenues will be forfeited.

Last, the authors suggest that the EU implement an export-import policy that is not discriminatory because it may have a snowball effect on other countries. Moreover, with the implementation of the RED II policy, the EU can also be seen as inconsistent in implementing and applying the GATT, which the EU has signed and approved.

${ }^{28}$ Ministry of Foreign Affairs, 'Menlu RI Desak Uni Eropa Perlakukan Minyak Kelapa Sawit Secara Adil' (Kemenlu, 2020) < https://kemlu.go.id/portal/id/read/1932/berita/menlu-ri-desak-unieropa-perlakukan-minyak-kelapa-sawit-secara-adil $>$ accessed 14 January 2021.

${ }^{29}$ Ministry of Foreign Affairs, 'Indonesia Sambut Positif Joint Working Group Minyak Nabati Uni Eropa-ASEAN Menuju Peningkatan Perdagangan' (Kemenlu, 2021) < https://kemlu. go.id/stockholm/id/news/10548/indonesia-sambut-positif-joint-working-group-minyak-nabati-unieropa-asean-menuju-peningkatan-perdagangan> accessed 26 January 2021. 


\section{Bibliography}

3Keel LLP and LMC International Ltd, Study on the Environmental Impact of Palm Oil Consumption and on Existing Sustainability Standards (Publications Office of the European Union 2018).

Adolf H, Pengaruh Perjanjian WTO/GATT-1994 Mengenai Penanaman Modal Asing Di Indonesia Dan Langkah Antisipasi Hukumnya (FH UNPAD 1998).

Antara S, 'Dubes Uni Eropa Bantah Larangan Impor Sawit Dari Indonesia' CNN Indonesia (2019) <www.cnnindonesia.com/ekono mi/20191212135827-92-456346/dubes-uni-eropa-bantah-larangan-imporsawit-dari-indonesia $>$ accessed 16 October 2020.

Dewi R, 'Implementasi Renewable Energy Directive Uni Eropa Sebagai Hambatan Non Tarif Perdagangan’ (2013) 1 Jurnal Interdependence $<$ https://core.ac.uk/ download/pdf/268076071.pdf $>$.

European Union, 'Directive (Eu) 2018/2001 of the European Parliament and of the Council of 11 December 2018 on the Promotion of the Use of Energy from Renewable Sources (Recast)' (Official Journal of the European Union, 2018) <https://eur-lex.europa.eu/ legalcontent/EN/TXT/?uri=uriserv:OJ.L_.2018.328.01.0082.01. ENG\&toc $=$ OJ:L:2018:328:TOC 9> accessed 26 October 2020.

Indonesia Association of Palm Oil Entrepreneur, 'Refleksi Industri Kelapa Sawit 2019 Dan Prospek 2020’ (GAPKI, 2019) < https://gapki.id/news/16190/ refleksi-industri-kelapa-sawit-2019-dan-prospek-2020> accessed 7 November 2020.

Indonesia Investments, 'Minyak Kelapa Sawit' (Indonesia Investments, 2017) $<$ www.indonesia-investments.com/id/bisnis/komoditas/minyaksawit/ item166\#: :text=Indonesia adalah produsen dan eksportir terbesar minyak sawit di dunia.\&text=Produksi minyak sawit dunia didominasi,eksportir minyak sawit yang terbesar $>$ accessed 16 October 2020 .

International Council on Clean Transportation, 'The European Commission's Renewable Energy Proposal for 2030' (ICCT, 2017) <https://theicct.org/sites/ default/files/publications/RED II_ICCT_PolicyUpdate_vF_jan2017.pdf $>$ accessed 16 October 2020.

Kadarukmi ER, 'Dampak Implementasi GATT/WTO Terhadap Ekspor Impor Indonesia’ (2013) 9 Jurnal Administrasi Bisnis.

Korah RSM, 'Prinsip-Prinsip Eksistensi General Agreement on Tariffs and Trade 
(GAAT) Dan World Trade Organization (WTO) Dalam Era Pasar Bebas' (2016) 22 Jurnal Hukum Unsrat <https://ejournal.unsrat.ac.id/index.php/ jurnalhukumunsrat/article/view/13198>.

Lendle A and Schaus M, Sustainability Criteria in the EU Renewable Energy Directive: ICTSD Information Note No 2, September 2010 (International Centre for Trade and Sustainable Development 2010).

Lilimantik E, Kebijakan Ekonomi Internasional (FPK UNLAM 2015).

Matsushita M, The World Trade Organization: Law, Practice, and Policy (3rd edn, OUP 2015).

McNair L, The Law of Treaties (OUP 1961).

Ministry of Foreign Affairs, 'Indonesia Sambut Positif Joint Working Group Minyak Nabati Uni Eropa-ASEAN Menuju Peningkatan Perdagangan' (Kemenlu, 2021) <https://kemlu.go.id/stockholm/id/news/10548/indonesia-sambutpositif-joint-working-group-minyak-nabati-uni-eropa-asean-menujupeningkatan-perdagangan> accessed 26 January 2021.

Ministry of Foreign Affairs, 'Menlu RI Desak Uni Eropa Perlakukan Minyak Kelapa Sawit Secara Adil' (Kemenlu, 2020) < https://kemlu.go.id/portal/ $\mathrm{id} / \mathrm{read} / 1932 /$ berita/menlu-ri-desak-uni-eropa-perlakukan-minyak-kelapasawit-secara-adil> accessed 14 January 2021.

News Desk, 'Millions of Indonesians to Be Affected by EU Palm Oil Policy: Japbusi' The Jakarta Post (2019) <www.thejakartapost.com/news/2019/04/24/ millions-of-indonesians-to-be-affected-by-eu-palm-oil-policy-japbusi.html> accessed 8 November 2020.

Rahayu SW and Sugianto F, 'Implikasi Kebijakan Dan Diskriminasi Pelarangan Ekspor Dan Impor Minyak Kelapa Sawit Dan Bijih Nikel Terhadap Perekonomian Indonesia' (2020) 16 DIH: Jurnal Ilmu Hukum.

Sefriani, Hukum Internasional: Suatu Pengantar (PTRaja Grafindo Persada 2010).

Stiadi AA, 'Potensi Dampak Penerapan RED II Terhadap Perekenomian Indonesia' (Psdr.lipi, 2020) <http://psdr.lipi.go.id/news-and-events/opinions/potensidampak penerapan-red-ii-terhadap-perekenomian-indonesia.html $>$ accessed 21 October 2020.

Suharto R, 'EU Renewable Energy Directive II Dan Hambatan Perdagangan' (Sawit Indonesia, 2019) <https://sawitindonesia.com/eu-renewable-energydirective-ii-dan-hambatan-perdagangan/> accessed 5 November 2020. 
Tim Bank Indonesia, Kerja Sama Perdagangan Internasional: Pejuang Dan Tantangan Bagi Indonesia (PT Elex Media Komputindo 2007).

UU no 7 Tahun 1994 tentang Pengesahan Agreement Establishing the World Trade Organization (Persetujuan Pembentukan Organisasi Perdagangan Dunia).

HOW TO CITE: Amanda Fadhilla Chairunisa and Imam Haryanto, 'Analysis of Renewable Energy Directive II on Trading of Indonesian Palm Oil Associated with the GATT' (2021) 36 Yuridika. 
Amanda Fadhilla: Analysis of Renewable Energy

--This page is intentionally left blank-- 